
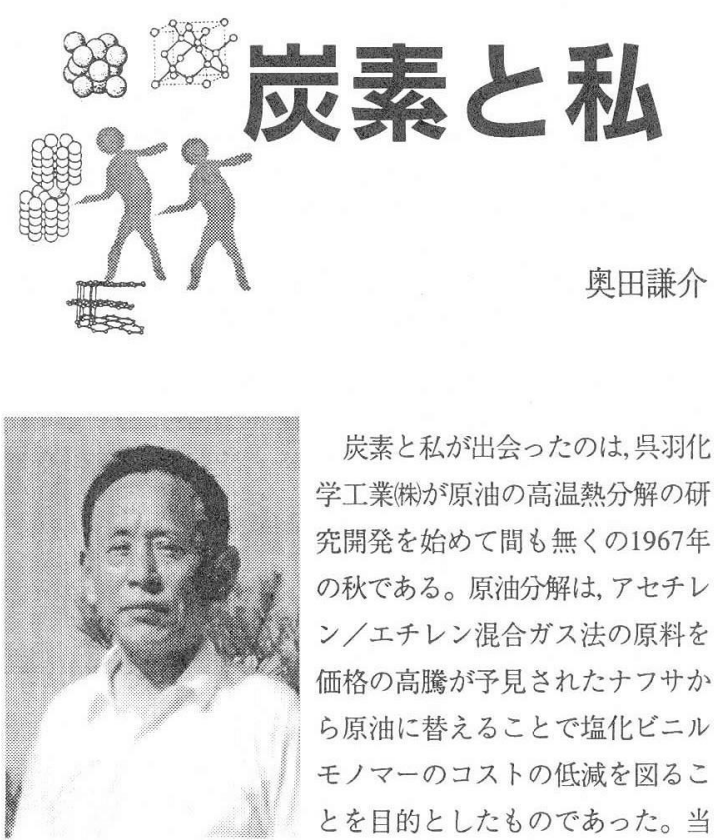

炭素と私が出会ったのは, 吳羽化 学工業(侏が原油の高温熱分解の研 究開発を始めて間も無くの1967年 の秋である。原油分解は,アセチレ ンノエチレン混合ガス法の原料を 価格の高騰が予見されたナフサか ら原油に替えることで塩化ビニル モノマーのコストの低減を図るこ とを目的としたものであった。当 然のことながら副生するタール, ピッチの比率が高く, これら の高度利用の研究開発も併行して進めることとなった。

当時, 私は財閥系の化学会社から転職のお誘いを受けてい た。米国留学などの影響もあって, 新しい仕事をしたいと考 えていた私は迷ったあげく, 吳羽への入社を勧めて下さった 大先輩の岩前 博さん（日本ラグビー界最初の海外遠征チー ムのスクラム・ハーフでクレハロンを開発）に御意見を伺っ た。原油分解をやってみたらということで, 入社以来続けて きたクレハロン（塩化ビニリデン樹脂）などの高分子材料関 連の基礎的研究の仕事を中断し, タール, ピッチの特性解析に 始まり, 炭素へと転化していった次第である。

炭素との関わり合いは, 世界初のピッチ系汎用炭素繊維製 造プラントができた70年頃には高分子から炭素への初期転化 の段階を終わり, 73年の太洋化研株)への出向とともに本格的 なものとなった（炭素材料の製造・販売のための東洋紡との 合弁会社)。その途端二つの問題が生じた。一つは第一次石 油危機で, 原油価格の相対的高謄をもたらし, やがて原油分解 そのものにも影響を及ほした。第二はピッチ系高性能炭素繊 維に関するL.S. Singer博士の米国特許であり,その後 20 年間 付合う羽目となった。

当時炭素緎維は新素材として関心をもたれてはいたが, ポ リアクリロニトリル系も含めて柱となる市場はなく, 用途開
発と価格の低減が最優先課題であった。尅羽の炭素䋐維はい わゆる先進複合材料用の新素材の要件である高強度, 高弾性 率を備えておらず, 日米欧の企業がしのぎを削ると同時に協 力して用途開発を進めてきてポリアクリロニトリル系とは異 なり, 別の用途を独自で開くこととなった。幸い半導体産業 の急成長, 自動車の燃費規制, 石綿の使用規制などの動向にも 助けられて, 独自の市場を確立できた。開発の中では,ピッチ 系炭素繊維強化コンクリートを全面使用したアルシャヒード モニュメントの建設 (83年, バグダット市, 鹿島建設) は忘れ ることのできない思い出である。

沉用炭素繊維の用途開発と併行して進めていた高性能炭素 繊維の開発はUCCによるThornel-Pの上市で予期せ展開と なった。一つは20社を越える国内企業が関与した稀にみる研 究開発ブームである。これがMe-too-ism,によるとしても, 炭 素の科学と技術の進歩には大いに寄与したと思っている。も う一つはSinger特許である。そもそも大谷杉郎先生の異方性 ピッチ特許がメソフェーズピッチ系炭素繊維の基本特許であ るにもかかわらず, Singer特許が米国でだけ成立したのは特 許制度 (先発明主義) の違いによるものである。その証拠に 西ドイッでは先願の大谷特許によって拒絶されている。69年 の暮れだったと思うが, 岩前さんからピッチは高さ (厚さ) で 考えろといわれたことがある。当時は繊維の開発には直接関 わっていなかったので具体的には検討しなかった。そこで本 気で考えていたらSinger特許と付合うこともなかったはずで, これが唯一悔やまれる点である。

四半世紀を越える炭素との関わり合いの中で, 炭素だけで なく, 複合材料や標準化の分野でも活動できたことは, 大谷先 生を始めとする炭素の関係者の㚈陰である。深く感謝 するとともに, 炭素との出会いはいつまでも大切にしておき たいと願っている。

\section{略 歷}

1930年12月 岡山県備前市に生まれる 1953年3月 京都大学理学部物理学科卒業 1953年4月京都大学化学研究所研究員 1954年7月 吳羽化成株式会社 (現呉羽化学工業株式会社) 入社 1965～66年 ブルックリン工科大学 (現ニューヨーク工科大 学) 博士研究員

1973 77年 太洋化研株式会社出向 1991年3月呉羽化学工業株式会社退社 技術コンサルタント 